\title{
Integration of Fishery Enterprises in the Primorsky Region: Economic Rationales and Ways of Their Realization
}

\author{
Olga V. Korneyko \\ Aleksander P. Latkin \\ Vladivostok state university of economy and service. 690014, Russia, Vladivostok, Gogol St., 41, 1506 \\ Email: olga30300@mail.ru
}

\section{Doi:10.5901/mjss.2015.v6n5s3p118}

\begin{abstract}
Development of globalization processes of the world economics is first of all shown through the increased intensity of integration processes. Scientific basis of integration were created and developed by many generations of scientists. The issue of what of the existing theories most precisely reflects the real motives of the enterprise structures planning the integration serves as a matter of scientific controversy. It is established that the major cause of the increasing number of economically unstable subjects of managing with the low innovative activity in fishery of Primorye is ignoring of its system nature. For the purpose of this problem solution the work determines the main types and motives of the strategic alliances creation, and offers possible ways of integration processes development. Fishery associations with the closed cycle "production-processingrealization" and an economic cluster are considered to be the most perspective ones among them. The creation of unified technological processes during the whole production way will revive the unified production control system that was destroyed in the 90th of the last century. Simplification of the access to new technologies, distribution of risks, organization of the sharing of knowledge and the fixed capital, the increasing competence of the personnel due to coaching and possibility of the professional experience exchange are the purposes of a cluster. The offered ways of integration processes development in fishery activities can become the most important instrument of the advantage ensuring in innovative processes. Besides, the integration of the managing structures will improve a coordination of their activity, the management of fishery, and give a focus and competitiveness to all economics in the Primorskiy Krai.
\end{abstract}

Keywords: cooperation, integration, fishery enterprises, region.

\section{Introduction}

In the course of privatization in Russia it was taken the wrong decision that the market transition is closely connected with a disaggregation and disintegration of the industrial production as a necessary condition for the development of competitive and market relations in the industrial sector. The disintegration of economic communications between enterprises was the result of such a decision (Latkin, 2009). Besides, the disaggregation of enterprises in the capitalintensive branches to one of which the fishery industry relates, had an anti-investment character. The intensive competition caused the failures of the market and the fishery enterprises began to compete at the price level, covering only variable expenses. In such conditions the financial resources are not enough for carrying out the active investment policy. Now the material basis of the fishery in Primorye is in a critical situation. The high level of physical and moral deterioration of the fishing fleet and almost complete the blast of its updating, the reduction of capacities of the extracting and overworking enterprises show it. The share of the unprofitable enterprises is great (table 1). Own sources for the renovation implementation of the fixed capital are not being formed, and credit sources have a short-term and mediumterm character. In spite of the fact that in recent years in the Primorskiy Krai fishery the tendencies of economic stability are observed, the production output makes one fifth part in relation to the similar indicator of 1989, and the total amounts of water bioresources production makes the third part of the volume of 1988. 
Table 1 - The results of the enterprises work of the Primorskiy Krai fishery in 2012 - 2014

\begin{tabular}{|c|c|c|c|c|}
\hline Name of indicators & Unit of measure & 2012 & 2013 & 2014 \\
\hline Fish capture and no fish objects of the trade & thousand tons & 831,9 & 798,0 & 778,0 \\
\hline $\begin{array}{l}\text { Production index according the form of activity "Processing and conservation of } \\
\text { fish and seafood" }\end{array}$ & $\%$ & 101,2 & 98,3 & 99,7 \\
\hline Production index according the form of activity "The fishery" & $\%$ & 112,5 & 96,4 & 88,0 \\
\hline Shipped own-produced goods on a fishing complex & mil. rub. & 27546,9 & 35315,0 & 36502,7 \\
\hline $\begin{array}{l}\text { Fishery share in shipment of own-produced goods of the industrial enterprises of } \\
\text { an edge }\end{array}$ & $\%$ & 13,5 & 14,6 & 13,9 \\
\hline Stream of commerce of the organizations for the fishery and fish breeding & mil. rub. & 23188,2 & 26632,1 & 27537,6 \\
\hline Output of fish products, including canned food & thousand tons & 669,2 & 667,3 & 646,6 \\
\hline Output of live, fresh or cooled fish, tons & thousand tons & 82,0 & 75,7 & 57,6 \\
\hline Output of canned food & rub & 119,20 & 146,3 & 146,6 \\
\hline Supplies to the domestic market & thousand tons & 263,0 & 232,0 & 215,5 \\
\hline Share of supplies to the domestic market in general production & $\%$ & 39,3 & 31,2 & 30,6 \\
\hline Export supplies & thousand tons & 452,1 & 568,4 & 523,2 \\
\hline Export share in general production & $\%$ & 60,7 & 76,5 & 74,3 \\
\hline Export in value terms & mil.\$ & 712,0 & 926,2 & 922,9 \\
\hline Number of enterprises & un. & 550 & 531 & 512 \\
\hline $\begin{array}{l}\text { Number of vessels, total } \\
\text { including: }\end{array}$ & un. & 329 & 324 & 320 \\
\hline large-capacity & un. & 71 & 71 & 65 \\
\hline medium-capacity & un. & 160 & 156 & 156 \\
\hline small-capacity & un. & 98 & 97 & 99 \\
\hline Share of profitable enterprises & $\%$ & 25,2 & 20,1 & 18,4 \\
\hline
\end{tabular}

A source: the table was made by the author on the basis of the Federal Service of Statistics data in the Primorskiy Krai

At the same time the experience of economically developed countries is evidence of a dominant of integration processes in production and dynamics of the postindustrial development. The development of globalization processes of the world economics and strengthening of economic entities interdependence of various countries have led to essential changes in the economic structure. In the industrial economics the main factor of economic growth was the deepening of public division of the labor, grocery, technological and professional specialization. In modern conditions an intercompany and interindustry research and production cooperation, consolidation and integration have the leading position.

The ranges growth of production, the increase in a share of the enterprise in the market by means of the enterprise structures integration can become the answer to new requirements to the forms and principles of the organization of a business conduct. Integration at a certain historical stage is a condition of the further increase in production, accumulation of the capital and expansion of functional communications, balances and synchronization of reproduction of the individual capitals of managing subjects.

It is known that the integration is understood as association of economic subjects, deepening of their interaction, development of communications between them. Economic integration is shown in the expansion and deepening of production and technological communications, sharing of resources, association of the capitals, in creation for each other the favorable conditions of the economic activity implementation, removal of mutual barriers (Zagashvili, 1999).

\section{Literature Review}

Scientific basis of the integration were created and developed by many domestic and foreign scientists' generations. The analysis of the existing theories of the integration has showed that there is no unified concept that is capable to explain the structure of the market in which the integrated enterprises prevail. In our opinion it is explained by the fact that in various economic conditions the determinants of the branch structure change, that causes a plurality of integration theories.

The concept of transactional costs considers the organization of the integrated structures in the context of minimization of the transaction costs connected with an information search, a conclusion of contracts, a legal cost, etc. (Coase, 1937 and Williamson, 1971, Klein B., Crawford R.G., Alchian A. A. (1978). The strategic management considers the integration as alternatives of the organic growth strategy (Harisov, 2009). Such aspect of the integration theory as a 
positive effect of range, completely justifies the high level of industrial concentration in the capital-intensive branches due to specialization of work and the administrative personnel, more effective use of capacities, and also at the expense of production possibility of by-products (McConnell and Brue, 1990). Supporters of the cross-cultural interaction theory claim that the economic integration has a linear positive influence on alliance stability, but curvilinear (negative) influence on alliance profitability. Moreover, when the economic integration is stronger, other variables, such as a joint management and procedural justice will have a great influence on alliance productivity (Luo, 2008). In the theory of circumstances and the theory of situations different types of unforeseen influences are investigated and it is claimed that the joint effects of the integration are modelled by the organization size. In the small organizations and more dynamic environment the positive effect from the integration strongly decreases (Burgers and Covin, 2014).

The integration increases the level of the capital concentration, i.e. increases the enterprise structure ranges, reducing the competition level on these or those segments of the market. May it be justified by the strengthening of development function of an innovative type of reproduction? In general, in economic literature it is possible to allocate two mutually exclusive concepts establishing interrelation and interdependence of the competitive environment and innovative activity. The classical political economy, based on A. Smith's works (Smith, 1776), postulated a negative influence of monopolization on innovative activity in the branch. It did not prevent K. Marx was not prevented by that thing in order to predict the leading role of the large enterprises in realization of capital-intensive technological innovations (Marx, (1990) [1867]). A possibility of application of the scientific organization of work by the large enterprises was an argument in favor of the integration processes.

The Marx's ideas were developed in Y. Shumpeter and J. Gelbreyt's works. So, in 1942 Y. Shumpeter investigated the influence of the enterprise size on its tendency to innovation, i.e. he resolved the issue: if an innovative function of the large enterprise structure in comparison with the small one amplifies (Schumpeter, 1942)? He has offered a hypothesis that in the concentrated markets the large enterprise structures are the main engines of the technological progress. It shoukd be specified that the enterprise structure is understood as set of the enterprises of various organizational and legal forms which are carrying out the activity on the innovative, risk basis. Only the large enterprise structures, thanks to the great circulations and good access to external financing, are capable to incur expenses of innovations and take on at once some projects. Due to a diversification they are better positioned for the nontrivial works implementation. The neoclassical model connects an economic power of the state with a power of large corporations, and the integration - with opportunities of the allocative efficiency increase (the overcoming of a problem of "a double extra charge") and creations of the barriers of an entrance on the way of potential competitors. Galbraith (1967) says that the large corporations make a basis of the industrial system and control all economics spheres, a production, a scientific and technical progress, a market, and capital investments. Of course, a nature of interrelations of the considered phenomena is more difficult, than Y.Shumpeter and J. Gelbreyt thought, and innovations and structure of the markets are endogenous variables depending on many factors: capital intensities of the branch and economy from a range effect, a stage of a life cycle of a new product, costs for R\&D, etc. However, a leadership of the large structures in innovations is obvious. It confirms the objective analysis of the comparative efficiency of the Russian and foreign enterprise structures which are different in size. Their indisputable advantages are connected with the following reasons:

- the security with resources and higher stability to risks of uncertainty;

- the lower transactional costs at transfer of knowledge;

- the modern innovations, as a rule, -are the result of carrying out R\&D on the professional and systematic basis that is generally peculiar to the large structures. Practically in all countries which are characterized by the high intensity of innovative activity, R\&D concentrates in the large companies. In such countries as the USA, Great Britain, Germany, South Korea, Japan and Finland R\&D needs more than 70\% of the enterprise expenses;

- in the number of branches (aircraft industry, metallurgy, pharmaceutics, chemistry, mechanical engineering for nuclear power, shipbuilding, etc.) a small business is not presented at all, and the competition there happens only between the major companies.

It is obvious that now a creation and effective use of the results of innovative activity are the most important conditions for the dynamic development of the fishery. The fishery enterprises of the Primorskiy Krai have a very small range of innovations and show an insignificant interest in the innovative development. The high level of physical and moral deterioration of the fishing fleet and almost complete the blast of its updating, a raw orientation of the Russian export and its noncompetitiveness at the world market, the reduction of capacities of the extracting and overworking enterprises are evidence of the low enterprise confidence of the fishery enterprises.

The comparative analysis of the industrial policy elements of America, Japan and Germany has revealed the identical mechanisms of an activization of innovative activity as assistance in assets consolidation of the branch enterprises for the purpose of the formation of several integrated competing structures, the state support of the research 
consortia formed by association of the efforts of competitor companies, the preferential taxation of the enterprises which are carrying out innovations for the purpose of the import substitution, selective protection against an import, restriction of the foreign investments in a number of the strategic branches. Thus, the strong industrial policy in capital-intensive industries is defined by a formation of the innovative infrastructure and simultaneous maintenance of the competitive environment in the branch markets.

However, M. Porter says that the above-mentioned mechanisms of the classical protectionist industrial policy are inefficient and anti-competitive (Porter, 1998). As an alternative M. Porter has put forward a concept of the branch clusters development which is mostly based on the neoclassical principles of the competition. The cluster theory characterizes a cluster as one of the organizational forms of the vertical and horizontal integration combination of the legally independent enterprises with a participation of the regional power and science. The cluster approach proved by $\mathrm{M}$. Porter assumes systemacy of study of the separate branch as a part of the complex of the interconnected sectors. The study of the theory of clusters has helped Sultanova to reveal the following priorities of the industrial innovative policy (Sultanova, 2008):

1) a role of the government is limited to a creation of the necessary infrastructure for the development of the new enterprises as a part of a cluster, including the transport, financial, educational, information and innovative sphere;

2) the state stimulates a local demand, initiating the high requirements to the production quality made by the enterprises of a cluster;

3) the state encourages the competition, promotes a decrease in the barriers of an entrance to the branch cluster that causes the innovations growth in the branch.

The integration processes of the interaction of the fishery enterprise structures of the Primorskiy Krai are widely presented in Vorozhbit's (2014), Latkin's $(2009,2011)$, Karaseva's $(2009,2010)$ works.

If the economic activity of the organizations of the fish sphere is not carried out on the innovative basis, there is a question: if it can be related to the enterprise? The ranges of this phenomenon and process are insignificant that suggests that we need to search the important backbone factors and tools causing a business expansion, so, an increase of the innovative activity efficiency of the fishery enterprises.

One of such factors is the integration. Considering a capital-intensive nature of the fishery, an imbalance of the individual capitals of managing subjects and destruction of the unified production cycle, the integration in the fishery enterprise structures can become the most important instrument of a business expansion, so, the innovations growth.

\section{Research Methodology}

The analysis of the associations' modern forms the integration processes are the basis of which, allowed the authors to generalize and systematize them on the basis of the specified classification signs in relation to the fishery (figure 1).

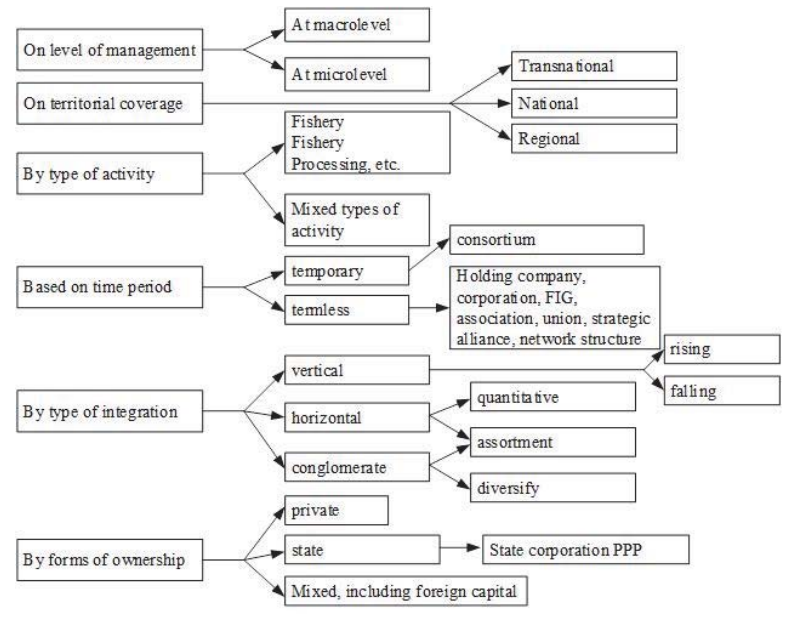

Figure 1 - The classification of modern forms of the integration in the fishery 
The fishery complex of the Primorskiy Krai is characterized by the form of the horizontal integration assuming unification of the enterprises within one kind of activity. Meanwhile, in foreign countries the vertical integration of the fishery structures is recognized as the most expedient. One of the vertical integration types is the vertical fusion consisting in cooperation of the enterprises and productions of the various branches for the purpose of the output one or several types of production within a unified technological chain.

The possible ways of the integration processes development in fishing activities demand the more detailed study. For the purpose of the identification of the motives inducing the companies to unite, we investigate and range the business problems in the Primorskiy Krai fishery, using the heuristic methods of the analysis based on the expert estimates of 52 managers, owners and specialists of the fishery enterprises. The conducted research allowed ranging the problems on a degree of their importance for the managing subjects (table 2).

The high ranks $(1,2)$ received the problems of a resource character (there are no financial means or the rights for water biological resources capture). Material problems (ranks 3-5) have the lower importance. On 6 - $\mathrm{m}$ a place settled down problems of relationship with authorities. Close a problem 7 rating - go and 8 - go ranks, connected with functioning of logistic infrastructure.

Table 2 - The assessment of problems, influencing the functioning and development of business in the fishery

\begin{tabular}{|c|c|c|}
\hline $\begin{array}{l}\text { Group } \\
\text { № }\end{array}$ & Problem & $\begin{array}{l}\text { A share from the } \\
\text { number of pollee, } \%\end{array}$ \\
\hline 1 & Lack of financial means & 63,0 \\
\hline 2 & Insufficient volume of quotas to water biological resources capture (WBR) & 52,6 \\
\hline 3 & High fuel prices, tariffs on railway services, electric power, port services & 48,4 \\
\hline 4 & Wear limit of a fleet (fishing and transport) & 40,5 \\
\hline 5 & Problems with an acquisition of the processing, trade equipment, replaceable spare parts at the domestic Russian market & 36,9 \\
\hline 6 & Relationship with authorities & 31,5 \\
\hline 7 & Problems with sale, storage of fish products in domestic market & 21,1 \\
\hline 8 & Others & 15,8 \\
\hline
\end{tabular}

A source: the table was made by the author on the basis of the expert estimates.

The conducted research testifies that the fishery business development is followed by many serious problems causing an existence of a great number of the inefficient, unstable and unstably functioning managing subjects. Based on the received results we classify the rationales to the integration depending on factors of the external and internal environment of the fishery enterprises (table 3). The analysis of the table data allows concluding that the environment factors in the prevailing degree are rationales to the integration of the fishery enterprise structures.

Table 3 - The classification of rationales to the integration of the fishery enterprise structures

\begin{tabular}{|c|c|c|}
\hline Classification sign & Rationales to the integration & Comments \\
\hline \multirow{4}{*}{ 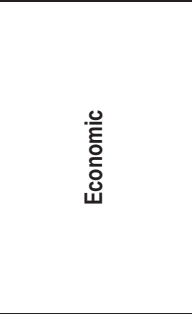 } & $\begin{array}{l}\text { Insufficient volume of quotas to water } \\
\text { biological resources capture (WBR) }\end{array}$ & $\begin{array}{l}\text { Enterprises which do not have the trade history, so, they must operate on } \\
\text { conditions of time - and bareboat charter schemes, they can unite with those which } \\
\text { has the long-term quotas }\end{array}$ \\
\hline & $\begin{array}{l}\text { High fuel prices, tariffs on railway } \\
\text { services, electric power, port services }\end{array}$ & $\begin{array}{l}\text { Having united, there is an opportunity to reduce need for current assets, to pass to } \\
\text { internal mutual settlements }\end{array}$ \\
\hline & $\begin{array}{l}\text { Wear limit of a fleet (fishing and } \\
\text { transport) }\end{array}$ & $\begin{array}{l}\text { Only large enterprises have an access to the bank credits which are sufficient for } \\
\text { carrying out a fleet renovation }\end{array}$ \\
\hline & Lack of financial means & $\begin{array}{l}\text { Having united, the companies reduce product cost at the expense of a scale effect, } \\
\text { receive lower transactional costs at transfer of knowledge, increase profitability of } \\
\text { production, so receive additional financial resources that allows to provide stability, } \\
\text { to prevent crisis }\end{array}$ \\
\hline \multirow{2}{*}{ 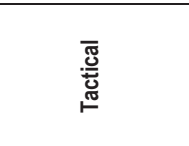 } & Fluctuations of market conditions & $\begin{array}{l}\text { An integrated structure has a possibility of carrying out the flexible assortment } \\
\text { policy according to fluctuations and changes of a demand. It reduces risks of the } \\
\text { failures of raw materials delivery for processing or product sales }\end{array}$ \\
\hline & Uncertainty of the environment & $\begin{array}{l}\text { It is known that a complex covering a considerable sum of elements is } \\
\text { characterized as a steadier one against the external changes }\end{array}$ \\
\hline$\frac{\bar{\pi}}{\mathrm{O}}$ & The social importance of the branch & $\begin{array}{l}\text { Branch is a city-forming in a number of regions of the country, one of the main } \\
\text { sources of workplaces creation. For the Primorskiy Krai the branch is a region- } \\
\text { forming. Integration will help to avoid the bankruptcy and to keep the employment } \\
\text { stability }\end{array}$ \\
\hline
\end{tabular}




\begin{tabular}{|l|l|l|}
\hline \multirow{2}{*}{} & $\begin{array}{l}\text { Problems with an acquisition of the } \\
\text { processing, trade equipment, } \\
\text { replaceable spare parts at the domestic } \\
\text { Russian market }\end{array}$ & $\begin{array}{l}\text { Enterprises and productions cooperation within a unified technological chain will } \\
\text { promote a restoration of the destroyed communications and production } \\
\text { restructuring. There will be a need to satisfy needs for the equipment due to own } \\
\text { productions }\end{array}$ \\
\cline { 2 - 3 } & $\begin{array}{l}\text { Problems with sale, storage of fish } \\
\text { products at the domestic market }\end{array}$ & $\begin{array}{l}\text { Association with the logistic, port companies will allow the last ones to be more } \\
\text { informed in needs for refrigerating capacities. Vertical integration of producers and } \\
\text { sellers will give the chance of the fish products realization, passing a great number } \\
\text { of intermediary speculators that will make it more available to the final buyer }\end{array}$ \\
\hline \multirow{2}{*}{$\begin{array}{l}\text { Regionalization of economy } \\
\text { Relationship with authorities }\end{array}$} & $\begin{array}{l}\text { Aspiration of the regional authorities to keep the branch complexes, to provide the } \\
\text { enterprises survival and development of the region }\end{array}$ \\
\cline { 2 - 3 } & $\begin{array}{l}\text { Association in the unions and associations allows to carry on a dialogue with } \\
\text { authorities, to solve the problems of businesses relationships with tax, customs } \\
\text { services, department of the fishery and WBR of the Primorskiy Krai, etc. }\end{array}$ \\
\hline
\end{tabular}

\section{Findings and Discussion}

The table shows that fishery managers have enough bases for the increase of the production concentration level and the capital in the fishery and creation of the horizontally and vertically integrated structures. Let's allocate the types of the fishery associations which are actively developing or perspective in the Primorskiy Krai (table 4).

Table 4 - Types of the integrated fishery enterprise structures

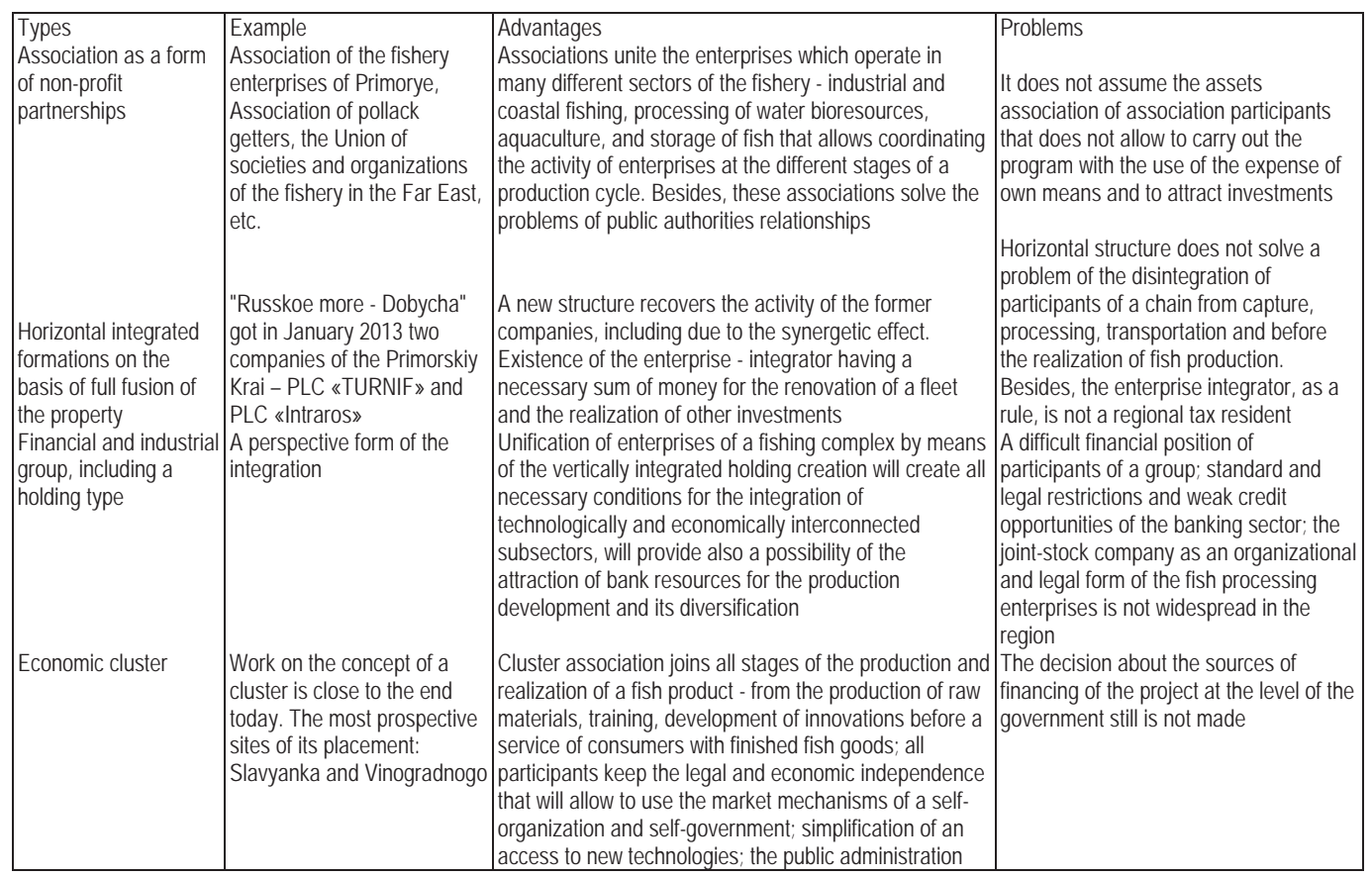

It should be noted that the integration processes of a vertical type have to happen from top to down, and not vice versa, i.e. the fishery company-initiator of the integration after the fusion with the fish processing and trade companies will have at the same time to carry out functions on processing of fish in areas of the sea trade and on her realization through a specialized distribution network. The penetration of processors and retailers into the fishing branch is hardly possible because of the last economic incentives absence. This conclusion finds a confirmation in theses of the economic theory about the identical viability of the large and small producer in the food industry and trade.

A creation of the unified technological processes during the whole production way will:

- firstly, avoid repeated defrosting and satisfy conditions on the preservation of a nutrition value of perishable goods to which fish and not fish objects of the trade refer; 
- secondly, bring indicators of the general profitability of the getter, processor and retailer into accord;

- $\quad$ thirdly, revive the control system of the unified production destroyed in the 90th of the last century "production - processing - production - sale".

As for a fishing cluster, it is obvious that the association of science efforts, the state and business provides advantages in the innovative processes. Simplification of the access to new technologies, distribution of risks, organization of the sharing of knowledge and the fixed capital, the joint R\&D, the increasing competence of the personnel due to coaching and possibility of the professional experience exchange, the transactional expenses reduction are the purposes of a cluster. The development of the competitive territorial production clusters is widely kept both by the scientific domestic community, and the power government institutions. Let's offer the following model of a regional fishery cluster (RFC) (figure 2).

The research of Japanese experience of the cluster development allowed the authors to make a conclusion on its efficiency and adequacy for an application in the Primorskiy Krai fishery. It is connected with the fact that, firstly, in Japanese experience of the cluster management, the innovative orientation of its functioning is expressed more accurately than in other countries. Secondly, this model combines the integration with the competition for the account of existence of the large fishing enterprises in one region round which the mobile fish processing small business develops. We have stated above that fish processors and sellers have no incentives to the integration. It is connected with the fact that the pricing mechanism in the fish branch of the Primorskiy Krai has an unbalanced character because of the existing disparity of the prices of the sphere of production and the address. For the solution of the problem of of inclusion of small and medium business stimulation in a fishery cluster the Japanese government grants to small enterprises the loans with the minimum interest rates, uses the accelerated depreciation of the equipment and other forms of tax incentives of investments, initiates the creation of innovative consortia, etc.

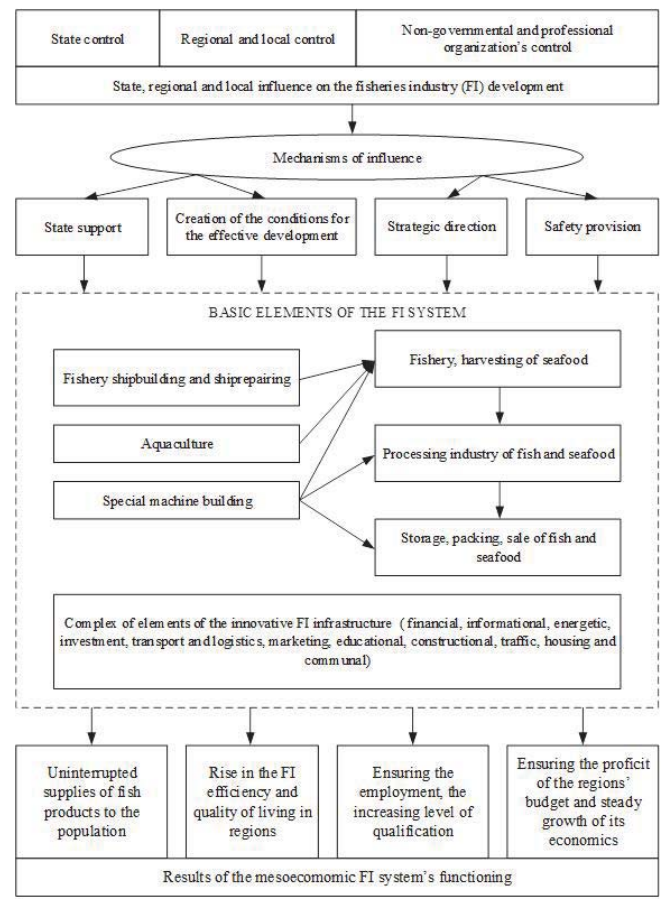

Figure 2 - The model of a regional fishery cluster (RFC)

Thus, small firms cannot address for privileges until they will not be built in the system of a cluster and to promote its structural improvement. The cluster mechanism of activization of innovative activity encourages the competition therefore it is more effectively realized in production of the differentiated production what the fish processing is that allows to satisfy most fully all ways of tastes of consumers both on internal and in foreign markets of fish products. 


\section{Concluding Remarks}

Summarizing the above information, it is possible to note that ignoring of its system nature is the main reason of the increasing number of economically unstable subjects of the market in the fishery of Primorye. For the purpose of the solution of this problem the article offers the possible ways of the integration processes development.

Despite the growing popularity of the cluster mechanisms of activization of innovative activity, in our opinion, the fishery associations with the closed cycle "production-processing-realization" are also an effective and adequate form of the integration. Thus, technologically difficult innovations in the fishing branch can be carried out in the conditions of the corresponding industrial policy of the state in the form of the priority financing of strategic investments, the organization of research consortia, support of the competitive environment between the large integrated associations, etc. The cluster mechanism of activization of innovative activity keeps the competitive environment due to the interaction of a large business with the small enterprises. The large enterprises, being a core of the development of the regional economics, will give it a focus and competitiveness, and the small ones will cause its flexibility and mobility, its market character. At the correct interaction and interrelation they form the steady system raising the economic security of both the Primorskiy Krai and all country.

The integrated structures offered by the authors covering all technological repartitions will allow building the address mechanism of redistribution of the added value, to eliminate partially the disparities of the developed system of pricing and to combine the efforts in realization of innovative functions of business.

\section{References}

Burgers, J. \& Covin G. (2014). The Contingent Effects Of Differentiation And Integration On Corporate Entrepreneurship. Strategic Management Journal, 2. DOI: $10.1002 / \mathrm{smj} .2343$.

Coase, R.H. (1937) The Nature of the Firm. 4 Economica. pp. 386.

Galbraith, J.K. (1967) The New Industrial State (Harmondsworth: Penguin Books).

Harisov, I.F. (2009) Prozessny podhod k upravleniyu companiyami posle sliyaniy i poglocheniy [The process approach to the management of the company's mergers and acquisitions after]. Problemy sovremennoy economiki [Problems of modern economy], 2. (145-154).

Karaseva, O.V. (2009) Integraziya - neobhodimoe uslovie strategicheskogog rasvitiya rybohosya'stvennogo kompleksa Primor'ya [The Integration - a necessary condition for the strategic development of fishery industry of Primorye]. Ecomomicheskie nauki [Economics]. 10. (240 - 246).

Karaseva, O.V. (2010) Instrumenty gosudarstvennogo regulirovaniya predprinimatel'stva v rybohosya'stvennoy deyatel'nosti. [The Tools of state regulation of entrepreneurship in fisheries management]. (Doctoral dissertation). Vladivostok, Russia.

Klein, B., Crawford R.G. \& Alchian A.A. (1978) Vertical Integration, Appropriable Rents, and he Competitive Contacting Process. Journal of Law and Economics. 21. (297-326).

Latkin A.P. \& Korneyko O.V. (2011) Osobennosti gosudarstvennogo regulirovaniya predprinimatel'stva $\vee$ rybohosya'stvennoy deyatel'nosti [The features of state regulation of business in fisheries]. Vladivostok, VSUES Publ. pp. 171.

Latkin, A.P. (2009) Upravlenie predpriyatiyami morehosya'stvennoy spezializazii [Management of enterprises of maritime specialization]. Vladivostok, VSUES Publ. pp. 368.

Luo, Y. (2008) Structuring interorganizational cooperation: the role of economic integration in strategic alliances. Strategic Management Journal, 29 (617-637). DOI: 10.1002/smj.677.

Marx, K. (1990) Capital: Critique of Political Economy, Volume I. Trans. Ben Fowkes. London: Penguin Books.

McConnell, C.R. \& Brue S. L. (1990). Economics: principles, problems, and policies. New York: McGraw-Hill.

Porter, M. (1998) Clusters and the new economics of competition, Harvard Business Review, 76 (6), 77-81.

Samuelson, P.A. (1967) The Monopolistic Competition Revolution in "Monopolistic Competition Theory: Essays in Honor of Edward H. Chamberlin. ed. Robert E. Kuenne, N.Y.: Wiley, pp. 105

Schumpeter, J.A. (1942) Capitalism, Socialism and Democracy. New York: Harper and Roe Publishers.

Smith A. (1776) An Inquiry into the Nature and Causes of the Wealth of Nations 1 (1 ed.). London: W. Strahan. Retrieved 2012-12-07.

Sultanova, D.Sh. (2008) Teoriya i metodologiya aktivisazii innovazionnoi deyatel'nosti na osnove pazvitiya konkurentnoi sredu [Theory And Methodology innovation activity jn the basis of the competitive environment]. (Doctoral dissertation). S-Petersburg, Russia.

Vorozhbit, O.J. (2014) Predprinimatel'skaya sreda kak factor vsaimodeystviya predprinimatel'skih struktur [Business environment as a factor-torus interaction of business structures]. Perm University Herald. Economy, (134-139).

Zagashvili, V. (1999) Integraziya Rossii v mirovoe hosya'stvo: strukturnye problemy [Russia's integration into the world economy: structural problems]. Mirovaya economika i mezhdunarodnye otnosheniya [World Economy and International Relations], 7 (22 29).

Williamson, O.E. (1971) The Vertical Integration of Production: Market Failure Considerations. Am. Econ. Rev. Vol. 61. pp. 112. 